\title{
Morphometry and Quantification of the Myenteric Neurons of the Cecum of Rats (Rattus norvegicus) Submitted to Experimental Chronic Alcoholism
}

\author{
Morfometría y Cuantificación de las Neuronas Mientéricas del Ciego en Ratones \\ (Rattus norvegicus) Sometidos a Alcoholismo Crónico Experimental
}

\begin{abstract}
Marli Aparecida dos Santos Pereira; Marcílio Hubner Miranda Neto; Márcia Alessandra Arantes; Sonia Lucy Molinari; Priscila Pereira \& Jacqueline Nelisis Zanoni
\end{abstract}

PEREIRA, M. A. S.; NETO, M. H. M.; ARANTES, M. A.; MOLINARI, S. L.; PEREIRA, P. \& ZANONI, J. N. Morphometry and quantification of the myenteric neurons of the cecum of rats (Rattus norvegicus) submitted to experimental chronic alcoholism. Int. $\mathbf{J}$. Morphol., 27(3):619-626, 2009.

SUMMARY: Morphometric and quantitative analyses were accomplished to study the effects of the consumption of alcohol above the size and density of the myenteric neurons of cecum of rats. Ten rats with 90 days were divided in the groups: control (C), and alcoholic (A). After 120 days of treatment with ethanol the cecum of both groups were collected, submitted it prepared of membranes that after carried out to Giemsa's technique, permitted to evaluate the neuronal density, in an area of $13.44 \mathrm{~mm}^{2}$, and measure the cell body area of 300 neurons by group. The alcoholic rats presented an increase in the number of small neurons and a reduction of the big and medium neurons. The neuronal density verified in alcoholic rats was significantly reduced regarding the controls rats, however, that reduction left of be statistically significant when was projected the neuronal density for the total area of cecum, since the macroscopic observation showed that the alcoholic rats presented a cecum dilated. The alcoholism induced a significant reduction in the final body weight of the rats of the GA, provoked enlargement of cecum of the rats causing to a big dispersion neuronal. The enlargement of cecum of the alcoholic rats is probably associated with the functional alterations of the myenteric neurons that have repercussions in the tone of the intestinal smooth muscle.

KEY WORDS: Alcoholism; Cecum; Myenteric neurons.

\section{INTRODUCTION}

Several works in different segments of the small and large intestine showed that the myenteric plexus suffers morphological, quantitative and physiological alterations capable to interfere with the operation of the intestine, when the rats were submitted to different experimental treatment, such as the malnutrition, alcoholism, ageing and diabetes (Gabella, 1989; Romano et al., 1996; Johnson et al., 1998; Sant' Ana et al., 2001; Natali et al., 2005; Zanoni et al., 2003; Pereira et al., 2003).

Zanoni et al. (1997) studied specifically the neurons of the myenteric plexus of cecum of diabetic rats with 2 and 8 months of age. They observed that the animals with two months of diabetes presented a reduction of the neuronal density due to enlargement of cecum, what leaves the ganglions scattered, causing to diminution of the number of neurons by unit of area; and in the animal with eight months the reduction of the neuronal density was attributed to the aging in conditions of diabetes.

The researches has shown the straight toxic effects of the ethanol above different organs and systems (Marks \& Wright, 1978; Palmer, 1989; Bode \& Bode, 2003), but they do not eliminate the possibility that the progressive malnutrition caused by the abusive use of the alcohol is associated with the respective clinical manifestations (Jacobs \& Sorrell, 1981; Achord, 1987; Lieber, 1991; 2003). Experimental studies with animals and voluntary humans, has shown that a sharp or chronic exposition of the mucous membrane of the small intestine to the alcohol occasion an 
inhibition of the absorption of the monosaccarides, several L-amino acid residues, lipids and adds vitamins (thiamine (B1), cobalamina (B12), pyridoxal-5-phosphate (B6), vitamin A and folic acid (Bode \& Bode, 1990; 2003; Morgan, 1982).

The motility of the small intestine is modified by the chronic and sharp consumption of alcohol (Bode \& Bode, 1990; Krishnamra \& Limlomwongse, 1987; Bode \& Bode, 2003). Disturbances of the synthesis of smooth muscule contractile proteins in small intestine, observed in rats receiving ethanol, might contribute it to you altered motor function (Preedy et al., 1993).

In the large intestine, the alcoholism looks to cause inhibition of the wave's not-propulsives and stimulation of the propulsives (Zeitume et al., 1991). The reflected one gastric-ileum-colon finds aggravated (Berenson \& Avner, 1981; Bouchoucha et al., 1991). The acceleration of the intestinal traffic associated to an inhibition of the absorption of the sodium and water in the jejunum and ileum (Pfeiffer et al., 1992) contributed for the tendency of the development of diarrhea in alcoholic (Bouchoucha et al.; Preedy et al.; Bode \& Bode, 2003).

Considering that myenteric plexus constituted itself of a web of nervous tissues functional and structurally specialized (Gabella, 1971), wait itself that several of the disorders gastrointestinal verified in the experimental conditions of malnutrition, diabetes, aging and, mainly the alterations in the intestinal mobility verified in alcoholic, have his origin in morphological, quantitative, biochemical and functional changes of the myenteric neurons.

Aiming at contribute with the few morphological researches existing in the literature in enteric neurons, in the condition of experimental chronic alcoholism, we proposed to analyze the cell body area and the density of the myenteric neurons of cecum of alcoholic rats.

\section{MATERIAL AND METHOD}

Obtaining of the groups. Ten male Wistar rats (Rattus norvegicus) initially ageing 2 months, were divided into two groups: control $(n=5)$ and alcoholic $(n=5)$. Both the groups received the same solid balanced ration for rodents. The alcoholic group were submitted to experimental ingestion of sugar cane brandy (trade mark "51", Pirassununga, SP., Brazil), diluted at $30^{\circ}$ G.L, as only source of distillate ethanol and water, during 210 days of experimental procedure e control group ingesting only water during the same period. Were measured the daily liquid consumption (water / alcohol), consume solid (chow) and the initial and final body weight. The animals were sacrificed through inhalation of ether ethilic. The cecum was retired, profiles were taken on a cardboard and the area was calculated in a computerized image analyzer (Image Pro Plus).

Obtaining of whole-mount. The cecum of 5 animals of each experimental group were washed with saline solution, filled with solution of Giemsa, without stretching the organ. The cecum was divided into two regions (Fig.1), the ventral face of cecum, between the smaller and biggest curvatures were submitted to whole-mount stained with the method of Giemsa (Barbosa, 1978), that consisted of: microdissection under stereomicroscope to remove the mucous layer and the submucous layer; stain with staining solution of Giemsa (methylene blue); dehydration; clearing in xylol, mounting between lamina and cover glass with synthetic resin Permount.

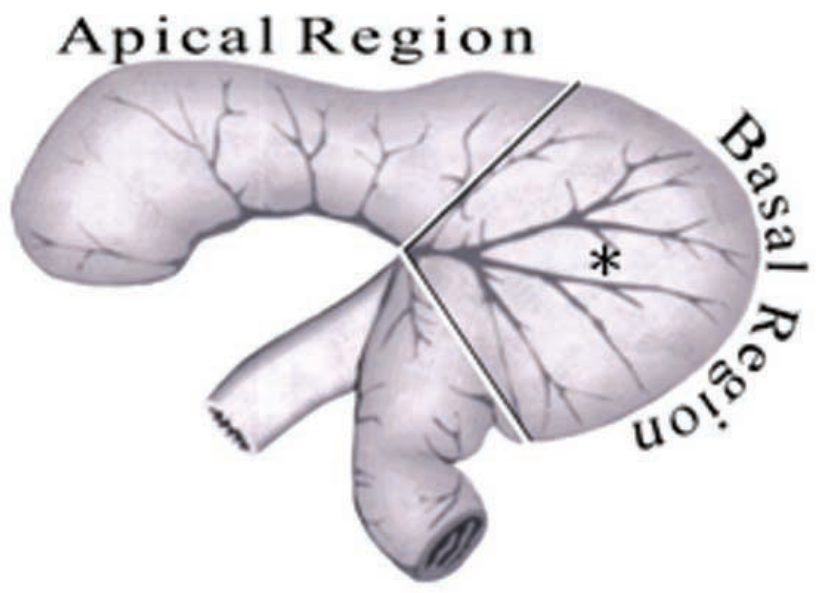

Fig 1. Schematic representation. The whole-mount were obtained of the ventral face of cecum, between the smaller and biggest curvatures $(*)$. Were despised the region apical and part distal of the basic region.

Quantitative and morphometric analysis. The Giemsastained whole-mounts were used for neurons counts and determination of the area of the cell body. The count was made under a light microscope (Leica DM RX), with a 40 $\mathrm{X}$, and all neurons of each field $\left(0.224 \mathrm{~mm}^{2}\right)$ were counted in a total of 60 randomly microscopic fields $\left(13.44 \mathrm{~mm}^{2}\right)$. The images were taken by a high resolution camera, transferred to computer, and recorded in a pen drive. The area $\left(\mu \mathrm{m}^{2}\right)$ of 300 cell bodies for each group was measured through the Image-Pro-Plus 3.0.1 images-analyses software (Cybernetics, Silver Spring, MD, USA). These results served for classify the myenteric neurons, as regards the size, in small, medium and large neurons. The lower neurons to on 
average subtracted of his standard deviation were considered small, the superiors to on average added to its standard deviation were considered large, and the intermediate between on average - standard error and on average + standard error were considered medium.

Statistical analysis. The variables that involved means were treated by the Test "t" of Student. The test of Chi-square was applied for comparison of the datas regarding the size of the neurons in the groups studied. The level of significance adopted was of $5 \%$. The datas were presented as medium \pm standard error.

\section{RESULTS}

The myenteric plexus in both of the groups (control and alcoholic) is formed by neurons that are grouped originating ganglions with format predominantly lengthened. The whole-mount stained with the method of Giemsa of the control rats present ganglions more near some of the others and are constituted by neurons densely grouped, while in the alcoholic rats (Fig. 2), the ganglions are more scattered and are formed by cell bodies of neurones found a little more remote some of the others.
The statistical analysis of the mean of the initial and final body weight; and of the diet solid and liquid consumption of the control and alcoholic rats were in the Table I.

The Table II shows the neuronal density, mean of the total area of cecum and the neuronal density projected for the total area of cecum of the control and alcoholic rats.

The analysis of the cell body area of the neurons of cecum of the group control varied between 16 to $1286 \mu \mathrm{m}^{2}$. Were considered as small the neurons that presented cell area $<295.1 \mu \mathrm{m}^{2}$; large neurons, that presented cell area $>379.3$ $\mu \mathrm{m}^{2}$ and medium neurons, that presented their area in the break between 295.1 and $379.3 \mu^{2}$. In the alcoholic rats the cell body varied between 22.07 to $1079.8 \mu \mathrm{m}^{2}$. They were considered as small that they presented cell area $<22.07$ $\mu \mathrm{m}^{2}$; large neurones the that presented cell area $>1079.8$ $\mu \mathrm{m}^{2}$ and medium neurons that presented their area in the break between 22.07 and $1079.8 \mu \mathrm{m}^{2}$.

The relative incidence of the small, medium and large neurons is shown in the Fig. 3. Through the test of Chi- square $(x=10.98$ and $p=5.99)$ and of the datas presented in the Fig. 3 verifies the existence of a bigger quantity of small neurons and a smaller quantity of big and medium neurons in the alcoholic rats, when compared to the control rats.

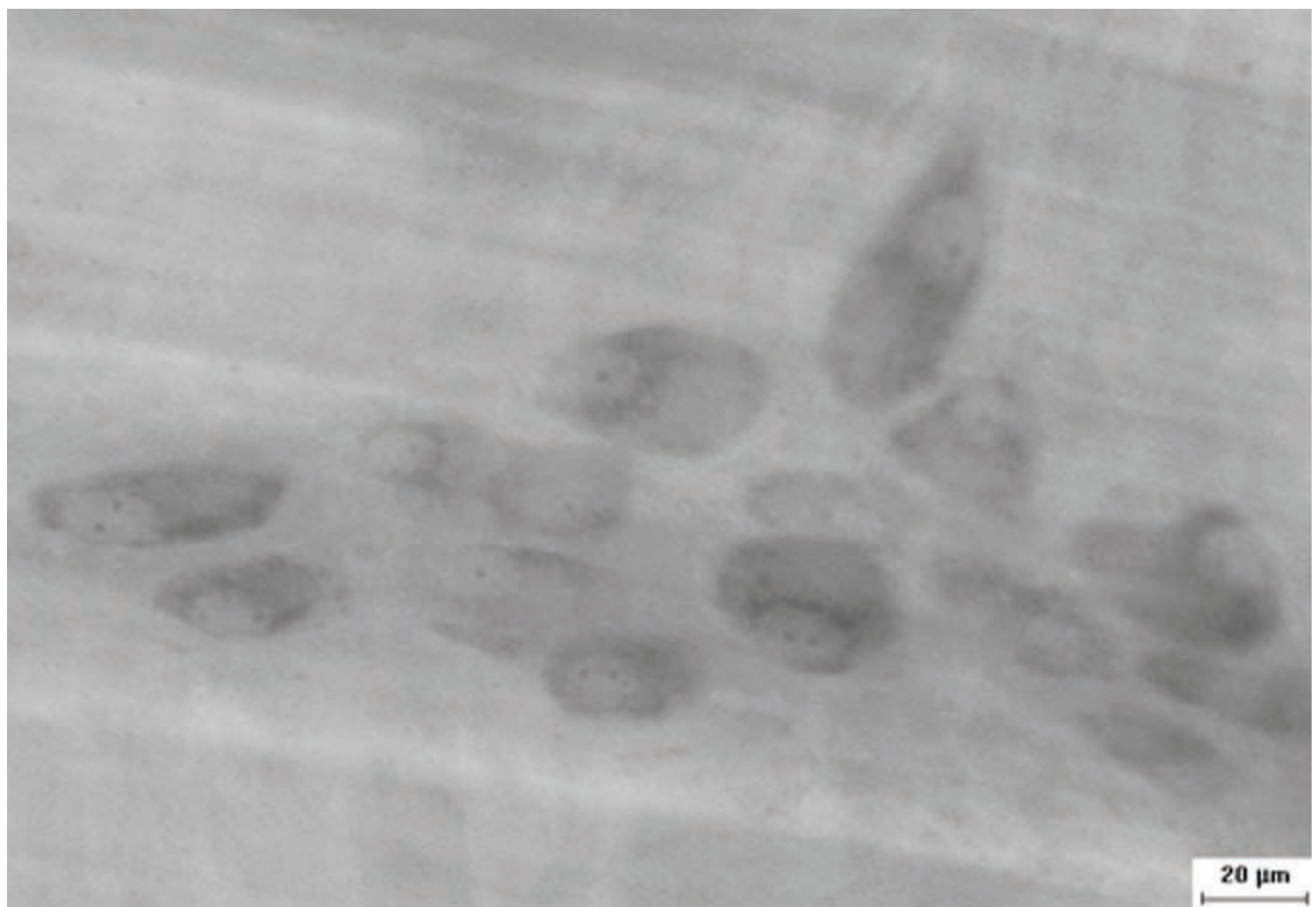

Fig 2. The whole-mounts of the cecum of alcoholic rats. Myenteric neurons stained with Giemsa. Calibration bar: $20 \mu \mathrm{m}$. 
PEREIRA, M. A. S.; NETO, M. H. M.; ARANTES, M. A.; MOLINARI, S. L.; PEREIRA, P. \& ZANONI, J. N. Morphometry and quantification of the myenteric neurons of the cecum of rats (Rattus norvegicus) submitted to experimental chronic alcoholism. Int. J. Morphol., 27(3):619-626, 2009.

Table I. Initial body weight (BWi) and final (BWf), consume daily of the solid diets (SD) and liquid (LD) of the control and alcoholic rats during 210 days of experimental treatment.

\begin{tabular}{lccrl}
\hline Groups & BWi $(\mathbf{g})$ & BWf $(\mathbf{g})$ & \multicolumn{1}{c}{ SD $(\mathbf{g})$} & \multicolumn{1}{c}{ LD $(\mathbf{m l})$} \\
\hline Control & $318.4 \pm 25.36 \mathrm{a}$ & $511 \pm 41.74 \mathrm{a}$ & $29 \pm 2.77 \mathrm{a}$ & $46.20 \pm 6.57 \mathrm{a}$ \\
Alcoholic & $305.2 \pm 21.9 \mathrm{a}$ & $422.4 \pm 42.5 \mathrm{~b}$ & $15.35 \pm 1.80 \mathrm{~b}$ & $26.27 \pm 3.9 \mathrm{~b}$ \\
\hline
\end{tabular}

Means followed by diferent letters in the same columm are diferent at level of $5 \%$. BWi ( $\mathrm{t}=0.39$; v.c. $=1.86)$. BWf $(\mathrm{t}=3.33$; v.c. $=1.86)$. $\mathrm{SD}(\mathrm{t}=9.55 ;$ v.c. $=1.86) . \mathrm{LD}(\mathrm{t}=5.77 ; \mathrm{v} . \mathrm{c} .=1.8)$.

Table II. Density of the myenteric neurons in the cecum of the control and alcoholic rats in an area of $13.44 \mathrm{~mm}^{2}$. Total area of cecum. Neuronal density projected in the total area of cecum.

\begin{tabular}{lccc}
\hline Groups & Neuronal Density & Total area $\left(\mathbf{m m}^{\mathbf{2}}\right)$ & neuronal density in the total area \\
\hline Control & $421.8 \pm 43 \mathrm{a}$ & $2832 \pm 817.8 \mathrm{a}$ & $88186.86 \pm 23885.21 \mathrm{a}$ \\
Alcoholic & $250.0 \pm 24 \mathrm{~b}$ & $4229 \pm 785.2 \mathrm{~b}$ & $79361.22 \pm 20256.08 \mathrm{a}$ \\
\hline
\end{tabular}

Means followed by diferent letters in the same columm are different at level of $5 \%$. Neuronal density $(\mathrm{t}=7.8 ; \mathrm{v} . \mathrm{c} .=1.86)$. Area of cecum $(\mathrm{t}=2.756$; v.c. $=1.86)$. Density projected for the total area of cecum $(\mathrm{t}=0.6$; v.c. $=1.86)$.

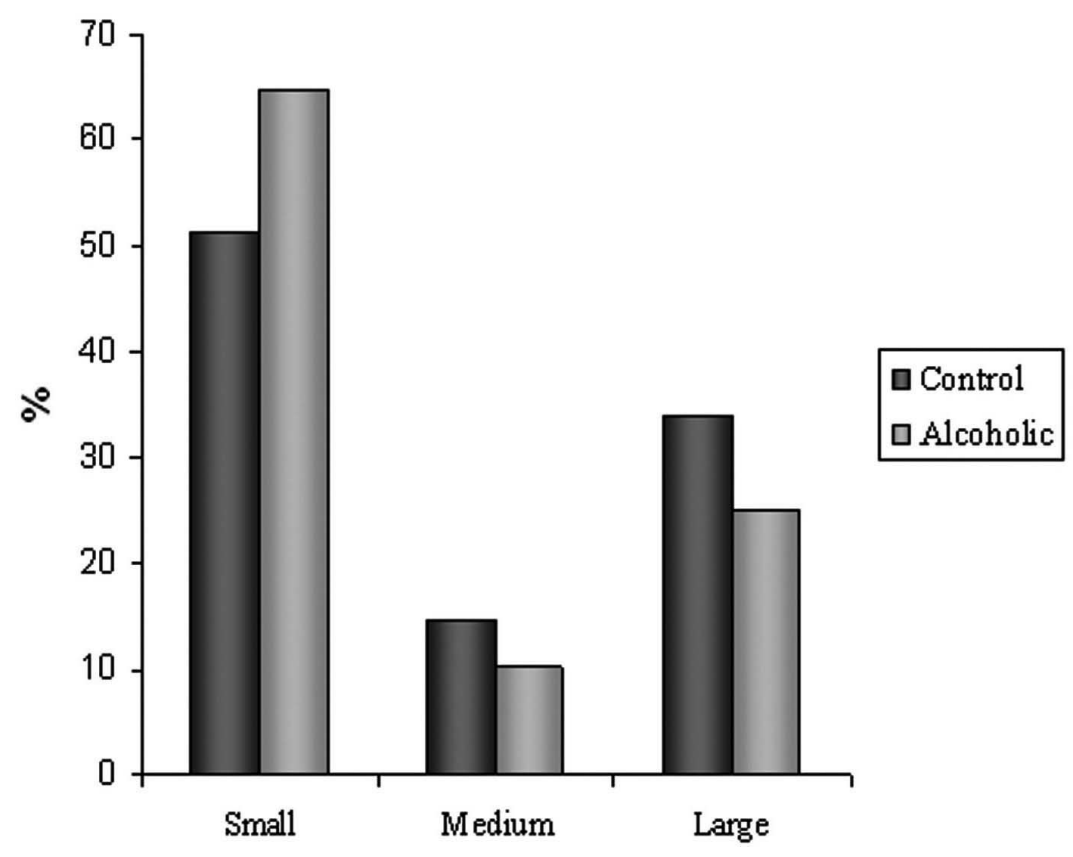

Fig. 3. Percentage of myenteric neurons classified in: small, medium and large in the cecum of control and alcoholic rats.

\section{DISCUSSION}

In our experiment, the body weight mean and consume a diet solid and liquid of the alcoholic rats was significantly minor when compared to the control rats. Those observations are similar to those found for Ratcliffe (1972) and Pereira et al. (2003) in the same experimental chronic condition of alcoholism.
We believe that the reduced body weight of our alcoholic rats must itself to the nutricional state of the animals, given the capacity of the ethanol for dislocate nutrients of high energy of the diet (Lieber, 1991; 2003). The reduced final body weight also was verified by Weinberg \& Vogh (1988) in rats that received liquid diet containing 
ethanol (alcoholic group) and in the animals that received liquid diet containing maltose-dextrin, that isocaloriclly is a substitute for the ethanol, when compared animals that received ration and water (group control). The authors concluded that the reduced body weight, in the alcoholic rats and isocalorics, were due to a diminished food intake than to the straight deleteries effects of the alcohol and his metabolits in the different organs and systems.

The myenteric plexus in cecum, in both of the groups studied, locates between the circulate and longitudinal layers of the externa muscle tunic, presenting ganglions with format predominantly lengthened. Ganglions with the same location and similar formats to them observed in this experience were described by Zanoni et al. (1997) studying the neurons of the myenteric plexus of cecum of diabetic rats.

In the relation cell body area of the neurons, we found in both of the groups, variations in the size. Those variations already were described in the literature and permit the classification frequent in small, medium and large neurones (Cook \& Burnstock, 1976; Romano et al.; Zanoni et al., 1997, Pereira et al.; Natali et al.).

The analysis of the cell body area of the neurons shows in the alcoholic rats a increase in the number of small neurons and a diminution of the large and medium neurons. As the straight toxic effect of the alcohol and his metabolits above small and large intestine, as the effect of the malnutrition alter its functions, prejudice the absorption of the nutrients (Lieber, 1991; 2003). During the chronic consumption of the alcohol, the active transport of diverse substances is affected, probably by inhibition of the ATPase of the intestinal epithelium, what also can injure the facilitated transport of nutrients like glucose, thiamine and aminoacids (Morgan, 1982; Dinda \& Beck, 1984; World et al., 1985; Bode \& Bode, 2003). In our experiment, the consumption of ration of the alcoholic rats was the half of the consumption of the control, committing the offering of essential aminoacids for synthesis of structural proteins. The lack of these proteins may have interfered with the repair and renewal of the citoplasmatics organelles of the myenteric neurons what would be able to be cause of the atrophy and cell death of some neurons verified in this experience.

In an area of $13.44 \mathrm{~mm}^{2}$, the control rats present 421.8 \pm 43 neurons, while the alcoholic rats present $250 \pm 24$ neurons. The density neuronal of the rats control resembles those found by Barbosa (1973) and Zanoni et al. (1997) in their quantitative studies of the cells nervous in cecum of control rats. The statistical analysis revealed that the alcoholic rats present a neuronal density significantly minor, when compared to the of the group control. However, that reduction stop being statistically significant when we project the neuronal density observed in our area of study $\left(13.44 \mathrm{~mm}^{2}\right)$ for the total area of cecum, seen that the macroscopic observation showed that the alcoholic rats presented a cecum dilated.

The enlargement of cecum in the animals of the alcoholic group leads to a broad dispersion of neurons, however the loss of the neuronal density of the alcoholic rats was of only $11.5 \%$ regarding the control rats, what suggests that the ethanol would be able to cause metabolic alterations in the myenteric neurons and in the muscle fibers by them inerved without however cause an expressive cell death. The significant enlargement of cecum verified in the alcoholic rats constituted itself in manifestation presented by the large intestine in different pathological conditions caused by microorganism (Chagas` disease), congenital (Hirschsprung disease) and metabolic alterations (diabetes), between other. Specifically in cecum, beyond the enlargement by us verified in the alcoholic rats, our group of research also verified enlargement experimentally provoked by the induction of the diabetes with streptozotocin (Zanoni et al., 1997). Second the authors the enlargement of cecum, is due to reduction of the neuronal density as a consequence of the diabetes mellitus. The reduction of the neuronal density in the chronic diabetes is associated with a peripheral neuritis that is consequent of the disturbances in the the polyol pathways, non enzymatic glycosylation and increase of the oxidative stress (Vinson et al., 1989; Vincent et al., 2004). In all the pathological conditions, the reason of that enlargement is linked the morphologics alterations and/or physiopathologics of the inervation. In the Chagas disease occurs destruction of enteric neurons and functional alterations in the muscle fibers caused by the Trypanosoma cruzi (Okumura et al., 1960; Smith, 1967; Tafuri et al., 1971), committing the muscle tone and the intestinal mobility originating the enlargements. In the alcoholism is broadly divulged his capacity of provoke malnutrition in special lack of vitamins of the complex B (Bode \& Bode, 1990; 2003). The lacks of these vitamins result in neuritis, that to our understanding, would be able to contribute as causes of the reduction of the tone and of the enlargement verified in cecum.

The neuronal density of the cecum of alcoholic rats was $11.5 \%$ more than that found in the control rats. Those animals received diet recommended by the National Research Concil \& National Health Institute (USA), with $22 \%$ proteic level, however, the alcoholic rats ingested only $50 \%$ of the amount consumed by the control, that suggests the existence of deficiency of proteins and vitamins, although do not reach the proteic malnutrition levels they adopted by Sant'Ana et al., approaches itself of the even. In studies carried out in the myenteric neurons in the colon, 
the last authors cited, found in rats that received ration with reduced protein for $8 \%$ and supplementation with vitamin of the complex $\mathrm{B}$, a reduction of $0.9 \%$ of the neuronal population, while the rats that received diet with protein content of $8 \%$, without the supplementation with vitamins of the complex B, the reduction of the neurons was of $26.7 \%$.

Besides, the speculative level, the diminution of the functions of the nervous cells, could be related with the metabolism of the alcohol which is going to elevate the formation of powerful oxidants in the cell (Nordman et al., 1992), which can initiate mischief to the biomolecules organic through the lipoperoxidation. The lipid peroxidation of the cell membranes of the axon and Schwann cells, causing the diminution of the function of the nervous cells was verified by Cameron et al. (1993) as a consequence of the diabetes mellitus, that similar to the alcoholism, presents an oxidative stress intensified.

PEREIRA, M. A. S.; NETO, M. H. M.; ARANTES, M. A.; MOLINARI, S. L.; PEREIRA, P. \& ZANONI, J. N. Morfometría y cuantificación de las neuronas mioentéricas del ciego en ratones (Rattus norvegicus) sometidos a alcoholismo crónico experimental. Int. J. Morphol., 27(3):619-626, 2009.

RESUMEN: Los análisis morfométrico y cuantitativo fueron hechos para estudiar los efectos del consumo de alcohol sobre el tamaño y densidad de las neuronas mientéricas del ciego de ratones. Diez ratones de 90 días, fueron divididos en los grupos: control (C), y alcohólico (A). Después de 120 días de tratamiento con etanol, los ciegos de ambos grupos fueron colectados, sometidos a preparación de membranas que después de coloreados por el método de Giemsa. Fue posible evaluar la densidad neuronal en un área de 13,44 mm², y medir el área del cuerpo celular de 300 neuronas por grupo. Los ratones alcohólicos presentaron un incremento en el número de neuronas pequeñas y una disminución de las neuronas medianas y grandes. La densidad neuronal verificada en los ratones alcohólicos fue significativamente reducida, en relación a los ratones controles. Esa reducción dejó de ser estadísticamente significativa cuando fue proyectada la densidad de las neuronas para el área del ciego, ya que la observación macroscópica mostraba que los ratones alcohólicos presentaban un ciego dilatado. El alcoholismo indujo una reducción significativa en el peso corporal final de los ratones del grupo A, provocó dilatación del ciego de los ratones, llevando a una gran dispersión neuronal. La dilatación del ciego de los ratones alcohólicos está probablemente asociada a alteraciones funcionales de las neuronas mientéricas que repercuten en el tono de la musculatura lisa intestinal.

PALABRAS CLAVE: Alcoholismo; Ciego; Neuronas mientéricas.

\section{REFERENCES}

Achord, J. Malnutrition and the role of nutritional support in alcoholic e liver disease. Am. J. Gastroenterol., 82:17, 1987.

Barbosa, A. J. A. Auerbach's plexus of the albino rat. I. Quantitative study of the ganglion and nerve cells in the caecum and colon. Rev. Bras. Pesq. Méd. e Biol., 6(5):253-62, 1973.

Barbosa, A. J. A. Técnica histológica para gânglios nervosos intramurais em preparados espessos. Rev. Bras. Pesq. Méd. e Biol., 11:95-7, 1978.

Berenson, M. M. \& Avner, D. L. Alcohol inhibition of retosigmoid motility in humans. Digestion, 22:210-5, 1981.

Bode, J. C. \& Bode, C. Alcohol malnutrition the gastrointestinal tract. In: Nutrition and Alcohol (Watson, R. R. \& Watzl, B. Eds.). Boca Raton, FL, CRC Press, 1990. pp.403-28.
Bode, C. \& Bode, J. C. Effect of alcohol consumption on the gut. Best Pract. Res. Clin. Gasteroenterol., 17:57592, 2003.

Bouchoucha, M.; Nalpas, B.; Berger, M.; Cugnenc, P. H \& Barbier, J. P. Recovery from disturbed colonic transit time after alcohol withdrawal. Dis. Colon Rectum, 34:111-4, 1991.

Cameron, N. E.; Cotter, M. A. \& Maxfield, E. K. Antioxidant treatment prevents the development of peripheral nerve dysfunction in streptozotocin-diabetic rats. Diabetologia, 36:299-304, 1993.

Cook, D. R. \& Burnstock, G. The ultrastructure of Auerbach's plexus in the guinea-pig. 1. Neuronal elements. J. Neurocytol., 5:171-94, 1976.

Dinda, P. K. \& Beck, I. T. Effects of ethanol on cytopasmic peptidases of the jejunal epithelial cell of the hamster. Dig. Dis. and Sci., 29:46-55, 1984. 
PEREIRA, M. A. S.; NETO, M. H. M.; ARANTES, M. A.; MOLINARI, S. L.; PEREIRA, P. \& ZANONI, J. N. Morphometry and quantification of the myenteric neurons of the cecum of rats (Rattus norvegicus) submitted to experimental chronic alcoholism. Int. J. Morphol., 27(3):619-626, 2009.

Gabella, G. Fall in the number of myenteric neurons in aging ginea pigs. Gastroenterology, 96:1487-93, 1989.

Gabella, G. Neuron size and number in the myenteric plexus of the newborn and adult rat. J. Anat., 109:81-95, 1971.

Jacobs, R. M. \& Sorrell, M. F. The role of nutrition in the pathogenesis of alcoholic liver disease. Sem. Liver. Dis., 1:244-53, 1981.

Johnson, R. J. R.; Schemann, M.; Santer, R. M. \& Cowent, $\mathrm{T}$. The effects of age on the overall population and on subpopulations of myenteric neurons in the rat small intestine. J. Anat., 192:479-88.1998.

Lieber, C. S. Hepatic, metabolic and toxic effects of etanol. Alcohol Clin. Exp. Res., 15:573-92, 1991.

Lieber, C. S. Relationships between nutrition, alcohol use, and liver disease. Alcohol Res. Health, 27:220-31, 2003.

Krishnamra, N. \& Limlomwongse, L. The in vivo effect of ethanol on gastrointestinal motility and gastrointestinal handling of calcium in rats. J. Nutr. Sci. Vitaminol., 33:8998, 1987.

Marks, V. \& Wright, J. Metabolic effects of ethanol. Clin. Endocrinol. Metab., 7:245-66, 1978.

Morgan, M . Alcohol and nutrition. Brit. Med. Bull., 38(1):219, 1982.

Natali, M. R. M.; Molinari, S. L.; Valentin, L. C. \& Miranda-Neto, M. H. Morphoquantitative evalution of the duodenal myenteric neuronal population in rats fed with hypoproteic ration. Biocell., 29(1):39-46, 2005.

Nordman, R.; Rubiere, C. \& Rovach, H. Implications of free radical mechanisms in ethanol induced cellular injury. Free Rad. Biol. Med., 12:219-40, 1992.

Okumura, M.; Britto, T.; Silva, L. H.; Silva, A. C. \& Corrêa Neto. A. The pathology of experimental Chagas's disease in mice: Digestive tract changes, with a reference to necrotizing arteritis. Rev. Inst. Med. Trop., 2:17-21, 1960.

Palmer, T. N. The biochemistry of alcohol and alcohol abuse. Sci. Prog., 73:1-15, 1989.

Pereira, M. A .S.; Molinary, S. L.; Souza, F. C; André, O. E. \& Miranda-Neto, M. H. Density and Morphometry of myenteric neurons of the ileum of rats subjected to chronic alcoholism. Int. J. Morphol., 21(3):245-50, 2003.
Pfeiffer, A. T.; Schmidt, N.; Vidon, C. \& Kaess, H. Absorption of a nutrient solution in chronic alcoholics without nutrient deficiencies and liver cirrhosis. Scand. J. Gastroenterol., 27:1023- 30, 1992.

Preedy, R. V.; Marway, J. S.; Siddiq, T.; Fasihuddin, A. A.; Hashim, I. A. \& Peters, T. J. Gastrointestinal protein turnover and alchol misuse. Drug Alcohol Depend., 34:110, 1993.

Ratcliffe, F. The effect of chronic ethanol administration on the growth of rats. Arch. Int. Pharmacodyn. Ther., 197:19-30, 1972.

Romano, E. B.; Miranda Neto, M. H. \& Cardoso, R. C. Preliminary investigation about the effects of streptozotocin-induced chronic diabets on the nerve cell number and size of myenteric ganglia in rat colon. Rev. Chil. Anat., 14(2):139-45, 1996.

Sant'Ana, D. M. G.; Molinari, S. L. \& Miranda-Neto, M. H. Effects of protein and Vitamin B deficiency on blood parameters and myenteric neurons of the colon of rats. Arq. Neuropsiquiatr., 59(3):493-98, 2001.

Smith, B. The myenteric plexus in Chagas Disease. J. Pathol. Bacteriol., 94(2):462-3, 1967.

Tafuri, W. L.; Maria, T. A. \& Lopes, E. R. Lesões do plexo mioentérico do esôfago, do jejuno e do colo de chagásicos crônicos. Rev. Inst. Med. Trop., 13(2):76-91, 1971.

Vincent, A. M.; Russell, J. W.; Phillip, L. \& Feldaman, E. L. Oxidative stress in the pathogenesis of diabetic Neuropathy. Endocr. Rev., 25(4):612-28, 2004.

Vinson, J. A.; Staretz, M. A.; Bose, P. \& Kassm, H. M. In vitro and vivo reduction of erythrocyte sorbitol by ascorbic acid. Diabetes, 38:1036-41, 1989.

Weinberg, J. \& Vogh, A. W. Effects of etanol consuption on the morphology of the rat seminiferous epithelium. Androl., 9:261-9, 1988.

World, M.; Ryle, P. \& Thonson, A. Alcoholic malnutrition and small intestine. Alcohol, 20(2):89-129, 1985.

Zanoni J. N.; Buttow, N. C.; Bazotte, R. \& Miranda-Neto, M. $\mathrm{H}$. Evaluation of the population of NADPH-diaphorasestained and myosin-V myenteric neurons in the ileum of chronically streptozotocin-diabetic rats tested wtih ascorbic acid. Auton. Neurosci., 104(1):32-8, 2003. 
PEREIRA, M. A. S.; NETO, M. H. M.; ARANTES, M. A.; MOLINARI, S. L.; PEREIRA, P. \& ZANONI, J. N. Morphometry and quantification of the myenteric neurons of the cecum of rats (Rattus norvegicus) submitted to experimental chronic alcoholism. Int. J. Morphol., 27(3):619-626, 2009.

Zanoni, J. N.; Miranda-Neto, M. H.; Bazotte, R. B. \& Souza, R. R. Morphological and quantitative analysis of the neurons of the myenteric plexus of the cecum of streptozotocin-induced diabetic rats. Arq. neuropsiquiatr., 55:696-702, 1997.

Zeitume, J. M. R.; Massuda, H. K. \& Betarello, A. Álcool e tubo digestivo. In: Alcoolismo: Diagnóstico e tratamento (Fortes, J. R. A. \& Cardo, W. N. Eds.). São Paulo, Sanvier, 1991. pp.75-87.
Correspondence to:

Marli Aparecida dos Santos Pereira

Morphophysiological Sciences Departament

State University of Maringá

Paraná

BRAZIL

Email: maspereira@uem.br

Received: 15-09-2008

Accepted: 28-05-2009 